\title{
Coagulation Factor VII
}

National Cancer Institute

\section{Source}

National Cancer Institute. Coagulation Factor VII. NCI Thesaurus. Code C16570.

Coagulation factor VII (466 aa, $\sim 52 \mathrm{kDa}$ ) is encoded by the human F7 gene. This protein is involved in both binding to tissue factor and the initiation of blood coagulation. 